\title{
DISCIPLINE INFLUENCE THE PEFORMANCE OF TEACHER WORKING PUBLIC PRIMARY SCHOOLS JUNIOR HIGH SCHOOL MANDAU KABUPATEN BENGKALIS
}

\author{
Eka Putra \\ Sekolah Tinggi Ilmu Ekonomi Riau \\ e-mail: ekaputra_cav@yahoo.co.id
}

\begin{abstract}
This research was conducted at junior school 8 Mandau Kecamatan Mandau. The purpose of this study was to determinance the effect of discipline influance the performance of teacher working in the office Mandau.The population in this were 45 teacher. In this study the sampling using saturated sample. Is aqual to 45 teacher. Data analysis in this research use descriptive and quantitative method.The result showed that the discipline of positive and significant of teacher working. The amount of influence of teacher working is disciplined by 53,9 percent while the rest 46,1 percent describing other independent variables that are not observed in this study.Recommendation can be submitted to the public junior School 8 Mandau Kecamatan Mandau, for even more attention is disciplined, this is because the disciplined has agreat influance, that is 53,9 percent.
\end{abstract}

Keywords: Discipline and teachers working

\section{Abstrak}

Penelitian ini dilakukan di SMP Negeri 8 Mandau Kecamatan Mandau. Tujuan penelitian ini adalah untuk mengetahui pengaruh disiplin yang mempengaruhi kinerja guru yang bekerja di kantor Mandau. Populasi dalam penelitian ini adalah 45 guru. Dalam penelitian ini pengambilan sampel menggunakan sampel jenuh. Apakah aqual menjadi 45 guru. Analisis data dalam penelitian ini menggunakan metode deskriptif dan kuantitatif. Hasil penelitian menunjukkan bahwa disiplin positif dan signifikan kerja guru. Besarnya pengaruh kerja guru didisiplinkan sebesar 53,9 persen sedangkan sisanya 46,1 persen menggambarkan variabel independen lainnya yang tidak teramati dalam penelitian ini. Rekomendasi dapat diajukan ke SMP negeri 8 Mandau Kecamatan Mandau, untuk lebih banyak lagi Perhatian disiplin, ini karena disiplin memiliki pengaruh besar, yaitu 53,9 persen.

Kata Kunci : Disiplin dan guru bekerja

\section{PENDAHULUAN}

Masalah yang diangkat dalam penelitian ini adalah tentang keterlambatan guru pada sekolah dalam melaporakan kinerja pada setiap periode. Selain itu juga sebagian guru masih menganggap penyerahan RPP tidak memiliki nilai guna atau tidak penting sehinggga kepala sekolah hanya sebatas menghimbau untuk melaporakan hasil kinerja semesternya.

Guru sebagai tenaga professional seharusnya memiliki pengetahuan dan pengalaman di bidangnya. Guru yang memiliki pengetahuan dan pengalaman yang cukup dalam bidangnya akan mampu melihat ke depan dalam peningkatan perkembangan unit pelayanan teknis (UPT). Kinerja guru dapat dilihat dari penguasaan guru terhadap kompetensi yang dimiliki sebagai tenaga profesional. Kinerja guru merupakan kemampuan dan keberhasilan guru dalam melaksanakan tugas-tugasnya. kinerja guru dipengaruhi oleh beberapa faktor yaitu sikap mental (motivasi kerja, disiplin kerja, etika kerja), 
pendidikan keterampilan, manajemen kepemimpinan, tingkat penghasilan, gaji, kesehatan, jaminan sosial, iklim kerja, sarana prasarana, teknologi dan kesempatan berprestasi.

Penilaian kinerja guru bertujuan untuk memperoleh informasi tentang kinerja guru dimasa lalu dan memprediksi kinerja guru dimasa depan. Selain itu tujuan penilaian kinerja guru adalah untuk mengetahui apakah suatu program pendidikan, pengajaran ataupun pelatihan tersebut telah dikusai pesertanya atau belum. Angka atau nilai tertentu biasanya dijadikan patokan, untuk menentukan penguasaan program tersebut. Jika dianggap belum menguasai, maka ia dinyatakan tidak lulus.

Kinerja (performance) mengacu pada kadar pencapaian tugas-tugas yang membentuk sebuah pekerjaan karyawan (Simamora dalam Agusty, 2006). Kinerja merefleksikan seberapa baik karyawan memenuhi persyaratan sebuah pekerjaan. Pengertian kinerja adalah pencatatan hasil yang dicapai dalam melaksanakan fungsi-fungsi khusus suatu pekerjaan atau kegiatan bekerja selama periode tertentu yang ditunjukkan melalui proses atau cara bekerja dan hasil yang dicapai. Sedangkan Byars and Rue dalam Agusty (2006) mendefinisikan kinerja merupakan derajat penyelesaian tugas yang menyertai pekerjaan seseorang. Kinerja adalah yang merefleksikan seberapa baik seseorang individu memenuhi permintaan pekerjaan. Berdasarkan definisi-definisi tersebut, menunjukkan bahwa kinerja merupakan hasil yang bersifat kualitatif dan kuantitatif.

Ada beberapa faktor penting yang berpengaruh terhadap meningkatnya kinerja guru, yaitu disiplin kerja guru. Disiplin kerja sering terabaikan dikalangan guru, hal ini dapat dilihat dari beberapa contoh antara lain: kedatangan ke sekolah terlambat, tidak berada di sekolah pada jam kerja, menunda pekerjaan, pulang sebelum waktunya dan lain-lain. Bagi mereka yang terpenting adalah mengisi daftar hadir.

Faktor-Faktor Yang Mempengaruhi Kinerja

Ada beberapa ahli yang menjabarkan tentang faktor-faktor yang mempengaruhi kinerja, diantaranya adalah :

1. Pendidikan

2. Keterampilan

3. Tingkat penghasilan

4. Jaminan sosial

5. Motivasi

6. Lingkungan dan iklim kerja

Indikator-Indikator Kinerja Guru

Deskripsi pekerjaan guru juga dijelaskan dalam SK Menpan Nomor 83 Tahun 1995 tentang Jabatan Fungsional Guru. Dalam SK tersebut dinyatakan bahwa tugas guru adalah:

a) Menyusun program pembelajaran,

b) Menyajikan program pembelajaran,

c) Melaksanakan evaluasi pembelajaran,

d) Menyusun dan melaksanakan program perbaikan dan pengayaan,

e) Menyusun dan melaksanakan program bimbingan di kelas yang menjadi tanggung jawabnya,

f) Menyusun dan melaksanakan program ekstrakulikuler.

Menurut Undang-Undang No.20 tahun 2003 tentang Sistem Pendidikan Nasional (SISDIKNAS) bahwa yang dimaksud dengan tenaga kependidikan adalah anggota masyarakat yang mengabdikan diri dan diangkat untuk menunjang penyelenggaraan pendidikan. Menurut Undang-Undang Guru dan Dosen No.14 tahun 2005, guru adalah pendidik professional dengan tugas utama mendidik, megajar, membimbing, mengarahkan, melatih, menilai, dan mengevaluasi peserta didik pada pendidikan anak usia dini jalur pendidikan formal, pendidikan dasar, dan pendidikan menegah. Dalam skripsinya Erintik Nur 
Azizah, dikemukakan beberapa indikator kinerja guru, antara lain: (1) Mampu membuat perencanaan, persiapan mengajar (2) Menguasai materi yang akan diajarkan (3) Menguasai metode pembelajaran dan strategi pengajaran (4) Memberi tugas-tugas kepada siswa, (5) Mampu mengelola kelas (6) Mampu melakukan penilaian dan evaluasi. Indikator penilaian terhadap kinerja guru dilakukan terhadap tiga kegiatan pembelajaran di dalam kelas yaitu pertama, perencanaan program kegiatan pembelajaran, kedua pelaksanaan kegiatan pembelajaran, dan ketiga evaluasi/penilaian pembelajaran.

Kerlinger dan Pahazur (Marjono 2007), mengemukakan, umumnya disiplin yang baik terdapat apabila seeorang datang ke kantor dengan teratur dan tepat waktu, apabila mereka berpakaian serba baik pada tempat pekerjaannya, apabila mereka menggunakan bahanbahan dan perlengkapan dengan hatihati, apabila mereka menghasilkan jumlah dan kualitas pekerjaan yang memuaskan dan mengikuti cara-cara kerja yang ditentukan.

Pendisiplinan karyawan adalah suatu bentuk pelatihan yang berusaha memperbaiki dan membentuk pengetahuan, sikap, dan perilaku karyawan sehingga para karyawan tersebut secara sukarela berusaha berusaha bekerja secara kooperatif dengan para karyawan lainserta meningkatkan prestasi kerjanya (Siagian, 2008). Kedisiplinan adalah kesadaran dan kesediaan seseorang menaati semua peraturan perusahaan dan norma-norma sosial yang berlaku ( Malayu, 2007).

Berdasarkan uraian diatas penulis menyimpulkan bahwa disiplin kerja adalah suatu keadaan dimana setiap individu malaksanakan peraturan yang berlaku dengan semestinya serta tidak adanya pelanggaran terhadap peraturan tersebut baik secara langsung mapun tidak langsung.

Menurut Singodimejo dalam Sutrisno (2011:94) adalah sebagai berikut: 1). Taat terhadap aturan waktu Dilihat dari jam masuk kerja, jam pulang, dan jam istirahat yang tepat waktu sesuai dengan aturan yang berlaku di perusahaan. 2). Taat terhadap peraturan perusahaan Peraturan dasar tentang cara berpakaian, dan bertingkah laku dalam pekerjaan. 3). Taat terhadap aturan perilaku dalam pekerjaan Ditunjukan dengan cara-cara melakukan pekerjaan-pekerjaan sesuai dengan jabatan, tugas, dan tanggung jawab serta cara berhubungan dengan unit kerja lain. 4). Taat terhadap peraturan lainnya diperusahaan Aturan tentang apa yang boleh dan apa yang tidak boleh dilakukan oleh para pegawai dalam perusahaan.

\section{METODE}

Jenis data yang digunakan dalam penelitian ini adalah deskriptif dan kuantitatif : yang menggunakan data primer yang merupakan data yang diperoleh langsung dari lokasi penelitian, yang mana dalam hal ini data diambil dari guru SMPN 08 Mandau yang berdasarkan sampel yaitu responden yang dituju. Serta data sekunder yaitu data yang diperoleh dari perusahaan dalam bentuk yang sudah jadi tanpa mengalami perubahan, seperti data tentang sebuah perusahaan, struktur organisasi dan data-data lain yang berkaitan dengan penelitian.

Populasi dalam penelitian ini adalah seluruh guru SMPN 08 Mandau yang berjumlah 45 orang. Untuk teknik pengambilan sampel yang akan dilakukan oleh penulissesuai dengan judul yang diteliti adalah sampling jenuh (sensus). Pengertian dari sampling jenuh atau sensus menurut Sugiyono (2008) "Sampling jenuh atau sensus adalah teknikpenentuan sampel bila semua anggota populasi digunakan sebagai sampel". Jadi sampel pada penelitian ini adalah seluruh anggota populasi yaitu guru SMPN 08 Mandau yang berjumlah 45 orang. Data yang dikumpul dianalisis dengan analisis Regresi Sederhana menggunakan program SPSS Versi 23 


\section{HASIL DAN PEMBAHASAN}

\section{Uji Vadilitas}

Uji validitas bertujuan untuk mengetahui item-item atau pertanyaan yang valid dalam menentukan sebuah variabel. Pengujian dilakukan dengan membandingkan nilai korelasi (r) hitung dengan $r$ tabel. Dimana kriteria pengujiannya jika nilai $r$ hitung $>r$ tabel maka dikatakan item pertanyaan tersebut valid dan jika nilai $r$ hitung $<\mathrm{r}$ tabel maka dikatakan item pertanyaan tersebut tidak valid dan dinyatakan pertanyaan tersebut gugur.

Uji validitas akan menguji masing-masing variabel yang digunakan dalam penelitian ini, dimana keseluruhan variabel penelitian memuat beberapa item pernyataan yang harus dijawab oleh responden. Adapun kriteria yang digunakan dalam menentukan valid tidaknya pernyataan yang digunakan dalam penelitian ini adalah apabila korelasi antara masing-masing indikator terhadap total skor konstruk menunjukan hasil yang signifikan dengan tingkat signifikasi $5 \% \mathrm{df}=\mathrm{n}-2(45-2)=43 \mathrm{r}_{\text {tabel }}=0.294$. Dan diperoleh nilai $r$ hitung seluruh pernyataan $>\mathrm{r}$ tabel $(0,294)$. Artinya adalah alat ukur yang digunakan validdan bisa digunakan sebagai alat pengumpul data.

\section{Uji Realibilitas}

Koefisien cronbach alpha yang lebih dari 0,60 menunjukkan keandalan (reliabilitas) instrumen. Selain itu, yang semakin mendekati 1 menunjukkan semakin tinggi konsistensi internal reliabilitasnya.

\section{Tabel 1}

Hasil Uji reliabilitas

\begin{tabular}{llll} 
Variabel & Cronbach's Alpha & Batas Reliabilitas & Keterangan \\
\hline Kinerja Guru & 0,848 & 0.60 & Reliabel \\
\hline Disiplin Kerja & 0,893 & 0.60 & Reliabel
\end{tabular}

Sumber : Data Olahan, 2018.

Hasil pengujian reliabilitas pada Tabel diatas menunjukkan bahwa nilai koefisien Alpha dari variabel-variabel yang diteliti menunjukkan hasil yang beragam dan variabel menghasilkan nilai Cronbach Alpha lebih besar dari 0,60. Dengan demikian dapat disimpulkan bahwa alat ukur yang digunakan dalam penelitian ini adalah reliabel.

\section{Uji Normalitas}

Pengujian normalitas data dilakukan untuk mengetahui apakah rata-rata data yang diperoleh berdistribusi normal. Hal tersebut dapat diketahui dengan melihat penyebaran titik-titik pada sumbu diagonal dari grafik $P$-P of Regression Standarized Residuals. Jika data (titik) menyebar disekitar garis diagonal, maka model regresi memenuhi asumsi normalitas. Namun, jika data (titik) tersebar acak maka model regresi tidak memenuhi asumsi normalitas. 


\section{Gambar 1 \\ Hasil Pengujian Normalitas}

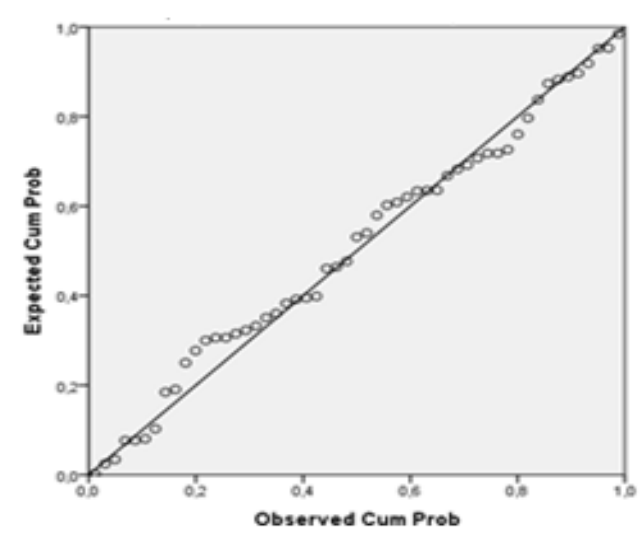

Sumber : Data Olahan, 2018.

Dari gambar diatas didapat dilihat bahwa data tersebar disekitar garis diagonal (tidak terpencar jauh dari garis diagonal). Dapat disimpulkan bahwa persyaratan normalitas data dapat terpenuhi. Dengan demikian pengujian statistik berupa uji determinasi dan uji $t$ dapat dilakukan dalam penelitian ini untuk menguji hipotesis.

\section{Persamaan Regresi Sederhana.}

Untuk mengetahui pengaruh variabel Disiplin kerja terhadap kinerja guru SMP N 8 Mandau, dilakukan analisis statistik. Berdasarkan hasil perhitungan SPSS versi 24 di dapat nilai persamaan regresi sebagai berikut :

\section{Tabel 2}

Hasil Uji Regresion

\begin{tabular}{|c|c|c|c|c|c|c|}
\hline & & $\begin{array}{l}\text { Unstan } \\
\text { Coeffic }\end{array}$ & & $\begin{array}{l}\text { Standardized } \\
\text { Coefficients }\end{array}$ & & \\
\hline Model & & $\mathrm{B}$ & Std. Error & & $\mathrm{t}$ & $\mathrm{Sig}$ \\
\hline & (Constant) & 14.183 & 4.885 & & 2,903 &, 006 \\
\hline 1 & Disiplin &, 850 &, 120 & ,734 & 7,087 &, 000 \\
\hline
\end{tabular}

Sumber : Data Olahan, 2018.

a. Konstanta sebesar 14,183, artinya jika faktor disiplin kerja (X) nilainya adalah 0, maka kinerja guru (Y) nilainya positif yaitu sebesar 14,183.

b. Nilai Koefisien faktor disiplin kerja $(0,850)$ menunjukkan bahwa setiap perubahan kenaikan variabel disiplin kerja sebesar 1 satuan, maka kinerja guru akan berubah naik sebesar 0.850 satuan dari perubahan variabel disiplin kerja.

c. Standar error $(e)$ merupakan variabel acak dan mempunyai distribusi probabilitas yang mewakili semua faktor yang mempunyai pengaruh terhadap Y tetapi tidak dimasukan dalam persamaan.

\section{Uji t}

Kebenaran hipotesis yang penulis ajukan secara partial dengan ketentuan :

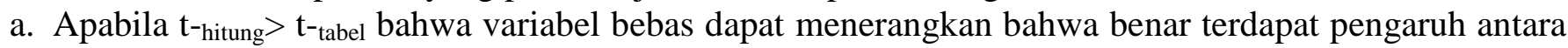
2 variabel yang diteliti. 
b. Apabila $\mathrm{t}_{\text {-hitung }}<\mathrm{t}$-tabel bahwa variabel dapat menerangkan tidak terdapat pengaruh antara 2 variabel yang diteliti.

Uji t ini dilakukan dengan membandingkan $t_{\text {-hitung }}$ dengan $t$-tabel pada signifikan $5 \%(\alpha=0,05)$

$$
\begin{aligned}
\mathrm{t}_{\text {tabel }} & =\alpha / 2: \mathrm{n}-\mathrm{k}-1 \\
& =0,05 / 2: 45-1-1 \\
& =0,025: 43 \\
& =2,017
\end{aligned}
$$

Variabel disiplin kerja (X) dengan menggunakan bantuan SPSS diperoleh t-hitung sebesar 7,087 dengan sig. 0,000. Maka bila dibandingkan pada $\mathrm{t}_{\text {-tabel }}$ pada signifikan $\alpha=5 \%$, yakni sebesar 2,017 dapat dilihat bahwa $t_{-}$-hitung lebih besar dari $t_{-t a b e l}$ atau sig. $<\alpha(0,05)(7,017>2.017$ atau $0,000<0,05)$. Dengan demikian dapat disimpulkan bahwa variabel $\mathrm{X}$ atau disiplin kerja mempunyai pengaruh positif dan signifikan terhadap kinerja guru.

\section{Koefisien Determinasi $\left(\mathbf{R}^{2}\right)$}

Apabila nilai $\mathrm{R}$ mendekati +1 maka secara bersama-sama variabel-variabel bebas tersebut mempunyai hubungan positif yang cukup kuat. Berikut hasil dari pengolahan data dengan menggunakan bantuan SPSS yang dapat dilihat sebagai berikut :

Tabel 3

Hasil Pengujian Determinasi $\left(\mathbf{R}^{2}\right)$

\begin{tabular}{llllll}
\hline Model & $\mathrm{R}$ & R Square & Adjusted R Square & $\begin{array}{l}\text { Std. Error of the } \\
\text { Estimate }\end{array}$ & , \\
\hline 1 &, $858^{\mathrm{a}}$ &, 737 &, 726 & 1,556 & \\
\hline
\end{tabular}

Sumber : Data Olahan, 2018.

Diperoleh nilai R. Square $\left(\mathrm{R}^{2}\right)$ sebesar $0.737(73,7 \%)$ ini menerangkan bahwa kinerja guru dapat diterangkan oleh variabel disiplin kerja yaknisebesar 73,7\%. Sedangkan sisanya sebesar $26,7 \%$ menggambarkan variabel bebas lain.

\section{Pengaruh disiplin kerja Terhadap Kinerja Guru}

Hasil penelitian menunjukkan bahwa disiplin kerja berpengaruh positif dan signifikan terhadap kinerja guru. Artinya makin ditingkatkan kedisiplinan kerja karyawan maka kinerja guru akan semakin baik, khususnya pada guru SMP N 8 Mandau. Demikian pula sebaliknya, semakin rendah perhatian pada kedisiplinan guru dalam bekerja maka tingkat kinerja guru juga akan semakin buruk atau akan semakin rendah.

Dari hasil penelitian, kedisiplinan para guru SMP N 8 Mandau mendapatkan penilaian yang tinggi sehingga memberikan dampak pada munculnya kinerja yang aan semakin baik pula. Hasil ini sejalan dengan hasil penelitian Darwis, 2016 Sekolah Tinggi Ilmu Ekonomi Riau Pengaruh Disiplin Kerja Terhadap Kinerja guru Sekolah Dasar Negeri 35 Air Kulim Kecamatan Mandau Kabupaten Bengkalis. Hasil penelitian menunjukan bahwa disiplin kerja berpengaruh positif dan signifikan terhadap kinerja Guru. Besarnya pengaruh disiplin terhadap kinerja Guru adalah sebesar sebesar 50.6\% sedangkan sisanya sebesar $49.4 \%$ menggambarkan variabel bebas lainnya yang tidak diamati dalam penelitian ini.Rekomendasi yang dapat diajukan kepada Sekolah Dasar Negeri 35 Air Kulim Kecmatan Mandau, untuk lebih lagi memperhatikan tentang disiplin kerja, hal ini dikarenakan disiplin kerja memiliki pengaruh yang besar, yaitu $50.6 \%$.

Berdasarkanuji koefisien determinasi diperoleh nilai R. Square $\left(\mathrm{R}^{2}\right)$ sebesar $0.737(73,7 \%)$ ini menerangkan bahwa guru SMP N 8 Mandau dapat diterangkan oleh faktor disiplin kerja yakni sebesar 
73,7\%. Sedangkan sisanya sebesar $26,7 \%$ menggambarkan variabel bebas lainnya yang tidak diamati dalam penelitian ini.

\section{KESIMPULAN}

Adapun simpulan yang dapat diambil adalah:

1) Hasil pengujian pada variabel disiplin kerja secara parsial diperoleh bahwa variabel disiplin kerja mempunyai pengaruh yang signifikan terhadap kinerja guru SMP N 8 Mandau.

2) Dari hasil uji hipotesis yang dilakukan diketahui bahwa variabel penelitian tersebut diatas, terbukti memberikan pengaruh yang signifikan terhadap kinerja guru SMP N 8 Mandau.

\section{SARAN}

Dari kesimpulan penelitian diatas, maka penulis dapat memberikan masukan sebagai berikut:

a. Diharapkan kepada SMP N 8 Mandau untuk dapat lebih meningkatkan lagi pada variabel disiplin kerja karena kedisiplinan guru sangat mempengaruhi kinerja guru SMP N 8 Mandau dengan memperoleh rata-rata tanggapan setuju. Dimana apabila disiplin kerja guru mendapat perhatian dari pihak sekolah seperti memberikan sanksi kepada guru yang terlambat maka akan mampu meningkatkan kinerja guru.

b. Diharapkan kepada pihak manajemen untuk meningkatkan atau minimal mempertahankan variabel tersebut guna meningkatkan kinerja guru SMP N 8 Mandau untuk masa yang akan datang.

\section{DAFTAR PUSTAKA}

[1]. Ahyari Agus, 2006. Manajemen Produksi: perencanaan sistem produksi, BPFE, Yogyakarta.

[2]. Bramasari 2004, keunggulan Korporasi penerbit PT. Elex Media Kompotindo, Jakarta.

[3]. Chattab, Nevizond.2007. Profil Budaya Organisasi. Alfabeta. Bandung.

[4]. Nielwaty, Elly, Prihati, Prihati, \& Zuhdi, Sulaiman. (2018). Kinerja Unit Dalam Mendukung Pengembangan Fakultas Ilmu Administrasi Universitas Lancang Kuning. Jurnal Niara, 10(2), 106114. Https://Doi.Org/10.31849/Nia.V10i2.1908

[5].Gasperz, Vincent, 2011. Manajemen Produktivitas Total Stategi Peningkatan Produktivitas Bisnis Global, Penerbil PT. Gramedia Pustaka Utama, Jakarta.

[6].Gomes, Faustin Cardoso, 2010. ManajemenSumberDayaManusia, CetakanKeempat, Penerbitandi Offset, Yogyakarta

[7].HafidhuddinDidin dan Hendri tanjung, 2013. Manajemen Syariah Dalam Praktik, Gema Insani Press, Jakarta.

[8].Hasibuan, Melayu, S.P., 2009. Manajemen Sumber Daya Manusia: Dasar dan Kunci Keberhasilan. Penerbit CV. Haji Masagung, Jakarta. 
[9].Malthis, L Robert \& Jakson,2009, Manajemen Sumber Daya Manusia, Rineka Cipta, Jakarta.

[10].MangkunegaraA.A. Anwar Prabu, 2005. Evaluasi Kinerja Sumber Daya Manusia,cet Pertama Fefika Adimata, Bandung.

[11].Moekijat, 2007.Manajemen Kepegawaian. Edisi Revisi, Penerbit Mandar Maju, Bandung.

[12].Nitisemito , Alex S., 2010, Manajemen Personalia : Manajemen Sumber Daya Manusia. Edisi Revisi, Penerbit Ghalia Indonesia, Jakarta.

[13]. Saputra, T. (2016). Pengaruh Motivasi Kerja Terhadap Disiplin Kerja Pegawai Pada Dinas Pemuda Dan Olahraga Provinsi Riau. Jurnal Niara, 8(2), 50-60.

[14].Sedarmayanti, 2010. Sumber Daya Manusia dan Produktifitas Kerja, CV. Mandar Maju, Bandung.

[15].Siagian, Sondang P., 2003. Munajemen Sumher Daya Manusia, Edisi Revisi, Penerbit Bumi Aksara, Jakarta 